\title{
2 What makes Csengery 64 important?
}

The hastily armed Arrow Cross militia immediately set upon the Jews. SS soldiers and armed Hungarians intruded into Csengery 64. A survivor, who played dead, said, that "in the apartments children, women, and men were shot haphazardly, altogether 21 of them." ${ }^{31}$

It is a fact that someone shot the unarmed tenants of Budapest's Csengery Street 64 on the night of October 15, 1944. It is also a fact that the Budapest People's Tribunal sentenced Piroska Dely, a notorious "Arrow Cross woman" to death for the massacre. The Budapest press covered the case as the first massacre committed by Arrow Cross Party members. The key questions however remain unresolved: whether Piroska Dely was the murderer and whether she was a member of the Arrow Cross. The people's tribunal trial did not identify the perpetrators with certainty; and since the analysis of witness statements leads to different conclusions this book will not offer definite answers either. Its aims are different.

Firstly, the examination of the Csengery Street massacre can shed light on a part of Hungarian past that is still a subject of political and scholarly debates. Doing so is particularly pertinent today. Since Hungary's recent populist turn, history writing increasingly focuses on simple people as central actors of history, while it simultaneously neglects methodological challenges in order to legitimize particular political goals and undermine the legitimacy of post-war political justice. $^{32}$

The chronology of the October 15, 1944 events at Csengery 64 can be reconstructed fairly well, as there are many although often contradictory sources. The chronology in the appendix (see appendix 1, 2 and 3) provides a framework that makes the event straightforwardly narratable and hopefully relatable and understandable too. As Pierre Nora holds:

[T] he event is always revolutionary, the grain of sand in the machine, the accident that shakes us up and takes us by surprise [....] It is best circumscribed from the outside:

31 The quote is from Pál Kádár's testimony to the Committee for the Investigation of Nazi and Arrow Cross Atrocities, February 24, 1945. http://konfliktuskutato.hu/index.php?option=com_ content\&view=article\&id=328:nyilas-terror-budapesten-1944-1945\&catid=39:dka-hatter\&Itemid= 203, last accessed January 23, 2019.

32 Petö Andrea, "Roots of Illiberal Memory Politics: Remembering Women in the 1956 Hungarian Revolution,” Baltic Worlds 10.4 (2017): 42-58. 
what is the event and for whom? For if there is no event without critical consciousness, there is an event only when, offered to everybody, it is not the same for all..$^{33}$

The versatility of available sources on the Csengery 64 event make it possible to analyse the perspective of victims and perpetrators alike, with which the historian aims to avoid the simplification of the historical narrative. By asking with Nora: "what is the event and for whom?" the analysis strives to contribute to a much-needed multilayered dialogue about a controversial segment of Hungary's past.

The murders at Csengery 64 differed from other killings not only because of the site of the murder but also because of their intimacy and their timing. I call these murders intimate because neither the industrial killing mechanism of the concentration camps nor the disciplined behavior typical of the military was present in Csengery 64. In a sense these events were like the widely discussed events in Jedwabne. ${ }^{34}$ Neighbors took part in killing and robbing their neighbors. The massacre's timing was also particular because it happened on the very day when the Arrow Cross Party seized power with the support of the occupying German troops. Previous research has already examined the October 15 and 16, 1944 actions of the Arrow Cross, when several thousand people were forcibly driven from the 8th district to Sebestyén Rumbach Street because of alleged armed resistance from forced laborers. After a swift protest from the side of neutral countries' representatives as well as some Hungarian notables, these people were let home in the middle of the night. ${ }^{35}$ The Csengery 64 massacre had strong ties to this series of events on the dramatic night of 15 October, 1944 but the people's tribunal in 1945 could not see these connections. This connection between this massacre and the "Jewish resistance" was later integrated via the testimonies of survivors.

The people's tribunal's witnesses unanimously claimed that the armed intruders were led by a woman, Piroska Dely. Through the case therefore we can examine a rarely researched dimension of Second World War, that is female perpetrators. Data suggests that in Hungary seven women were sentenced to death

33 Quoted by Shoshana Felman, "Theaters of Justice. Arendt in Jerusalem, the Eichmann Trial, and the Redefinition of Legal Meaning in the Wake of the Holocaust," Critical Inquiry 27.2 (2001): 201-238, 210.

34 Jan Gross, Neighbors: The Destruction of the Jewish Community in Jedwabne, Poland (Princeton: Princeton University Press, 2001).

35 Randolph L. Braham, Politics of Genocide: the Holocaust in Hungary (Detroit: Wayne State University Press, 2000), 155-157. 
as war criminals. ${ }^{36}$ Piroska Dely is a good example for the independent, "new" working woman of the interwar times. Her story reveals the political and emotional consequences of women's non-elite paid employment. To be a wage earner in the city profoundly shaped the experiences and political motivations of this generation of women. Among them the largest and least organized group of employed women were the domestic servants, followed by women factory workers. ${ }^{37}$ For these Hungarian women who, like Dely, experienced both the difficulties of gaining employment and discrimination against women in workplace, only the far right offered a viable political alternative. This was largely due to the fact that during Regent Horthy's decades long anti-communist governance the leftist alternatives - the trade unions and the social democratic party got sidelined as the left was blamed for Hungary's devastating loss after the First World War. The literature about post-war political justice mentions Dely as a "woman with agency," who as an "Arrow Cross woman" uncritically embraced far right thoughts, discourse and actions; but it is still a question whether she had official ties to the Arrow Cross Party. ${ }^{38}$

The sources on Csengery 64 also allow for an in-depth analysis of systematic plundering of Hungarian Jewry. Hungarian Jews were first deprived of rights and dispossessed by way of bureaucratic decisions, then, after their deportation, as no one expected them to return, their belongings were considered free prey. ${ }^{39}$ The systematic stripping of Jewish citizens of their money and assets was a part of their dehumanization. ${ }^{40}$ Still, in comparison with Poland, where German

36 On uncertainties concerning the numbers, see Pető Andrea, "Problems of Transitional Justice in Hungary. An Analysis of the People's Tribunals in Post-War Hungary and the Treatment of Female Perpetrators," Zeitgeschichte 34 (November-December, 2007): 335-349; Karsai László, “The People's Court and Revolutionary Justice in Hungary, 1945-1946," in The Politics of Retribution in Europe. World War II and Its Aftermath, ed., Deák István, Jan T. Gross, and Tony Judt, 233-252 (Princeton: Princeton University Press, 2000).

37 Balázs Sipos, Women and Politics: Nationalism and Femininity in Interwar Hungary (Trondheim: Studies on East European Cultures \& Societies, 2019).

38 It is crucial to separate the concepts "woman of the Arrow Cross" (nyilasnó) and "Arrow Cross woman" (nyilas no"). "Woman of the Arrow Cross" signifies women with ties to the Hungarian far-right party, while "Arrow Cross woman" has been historically used for those women, who at the end of Second World War participated in violent actions, such as robbery, plunder, and even murder, but had no direct connection to the party.

39 On the institutionalized aspects of the dispossession of Hungarian Jewry, see Kádár Gábor, Vági Zoltán, Hullarablás. A magyar zsidók gazdasági megsemmisitése (Budapest: Jaffa, 2005). 40 On the situation of Jews who returned to Paris, see Leora Auslander, "Coming Home? Jews in Postwar Paris," Journal of Contemporary History 40.2 (2005): 237-259. 
"cleansings" set an example, ${ }^{41}$ in Budapest the shaming and plundering of Jews was not an inescapable historical reality, partly because of the brevity of German occupation, and partly because of the general chaos of Arrow Cross rule. There was room for individual negotiation, as we will see from the variegated stories of Csengery 64 tenants. In other words, in the fall of 1944, with the Red Army on its way to Budapest, pillaging by private individuals was not a "normalized" behavior in the Hungarian capital. Csengery 64 survivors claimed that before the armed people who wore some kind of a uniform entered the house there was a gunshot outside. The gunshot was probably the perpetrators' attempt at an alibi: they could claim that they entered the house to restore order after an assumed armed mutiny. This suggests that at that point maintaining some resemblance of legality still mattered. ${ }^{42}$ The fact that police investigators came to examine the location after the massacre also offers evidence that it was an isolated action of crime and not a concerted effort by the collapsing Hungarian state administration. ${ }^{43}$

Most sources suggest that the Csengery massacre was primarily an armed robbery driven by greed and the belief that the perpetratrators could get away with the crime. After the building was officially marked as a yellow star house on June 21, 1944 its Christian janitors, József Strucky and his wife stayed in the house. The family safeguarded Jewish assets in exchange for money; they also hid Jews at great risk and for great monetary compensation, and lastly, they played a crucial role in the robbing of the Jewish tenants on October 15. After the next wave of deportations in November 1944, the janitors arbitrarily occupied the best apartment of the building. From February 1945, that is when some of the tenants returned from deportation, the janitors went on living among the people whom they robbed and betrayed but now back in their original apartment. After October 15, 1944 - and before the Soviet troops arrived the janitors even had the presence of mind to collect the Persilschein (see appendix 4) that is a paper in which the Jewish tenants expressed gratitude for the protection they had allegedly received. Therefore, the story of Csengery 64 also contributes to the ever-richer rescuer literature, as it shows that the motivation

41 Tomasz Fryde, "The Pazifizierungsaktion as a Catalyst of Anti-Jewish Violence. A Study in the Social Dynamics of Fear," in The Holocaust and European Societies, The Holocaust and its Contexts, ed., Frank Bajohr and Andrea Löw, 144-166 (London: Palgrave, 2016).

42 Interview (April 1, 2005).

43 Állambiztonsági Szolgálatok Történeti Levéltára (ÁBTL - Historical Archives of the Hungarian State Security Services), V 48889, 17654/1949. 34. On the responsibility of Hungarian police organizations, see Veszprémy László Bernát "Népirtás és mozgástér. A Magyar közigazgatás felelőssége az 1944-es deportálásokban és a nyilasterrorban,” Archivnet 18.2 (2018). 
behind hiding Jews could have been driven by financial considerations besides empathy or morals. Motives are hard to reconstruct retrospectively, but in the case of Csengery 64 it was clear which tenants could and which could not remunerate the janitors' services, and there were survivors from both groups who later held the Struckys accountable for lack their of empathy and morals. Upon their return from deportation, the building's Jewish tenants were shocked to find their clothing and other personal items in the janitors' apartment. Through the microhistorical analysis of how wealth disappeared and how new wealth was born within one house, this book attempts to nuance the commonly perceived black and white image of perpetrators and rescuers in Hungarian historiography. ${ }^{44}$

I was able to personally meet the survivors of Csengery 64, and as they honored me with their trust, I listened to them recounting that fatal day. The juxtaposition of these interviews with other accessible sources (the people's tribunals' papers, contemporary press, photographs) created an idiosyncratic base of resources, which made possible the examination of connections between memory, trauma, and gender. ${ }^{45}$ At the same time the most important sources, that is the interviews and the people's tribunal testimonies, posited a tremendous methodological challenge since these personal narratives represent a different temporality of interpretation and are subject to change. Just as important, the site of remembrance determines how remembrance is framed. The survivors and witnesses talked about the event differently on the house's corridor or during a family dinner, and again differently in their denunciation letters sent to the police, then during the police hearings, later as witnesses for the people's tribunal, and differently again during the oral history interviews. The audience and the circumstance determines what story is told and how it is being told.

As a first step I tried to establish who was where in the house, i.e. who could hear or see what happened during the night of October 15, 1944. I went around Csengery 64 several times and based on my knowledge of the premises I can claim that the testimonies do not fully reconstruct the story. By examining the testimonies, and the recordings of the preliminary police hearings, and the verdict, it is traceable how the narration of the events became "simplified." The parallel events were translated into legal terms which resisted complexities. The court wanted to establish a linear story about the event knowing what has happened, while the survivors wanted to tell their own, often different story. This

44 For more on this, see Randolph Braham, "Rescue Operations in Hungary: Myths and Realities,” East European Quarterly 38.2 (2004): 173-203.

45 On the court trial as the space of memory production, see Inga Markovits, "How the Law Affects what we Remember and Forget about the Past: The Case of East Germany," Law and Society Review 35.3 (2001): 513-563. 
process suited the political expectations and tendencies of the time. During the people's tribunals' trials, a ritualized language was developed through which the traumatic, unspeakable events of the Holocaust were translated into legal categories, which in turn made certain deeds punishable. This process evoked traumatic memories, or in Ross Chambers's words, "orphanated memories" that fundamentally determine the interpretation of events within the triangle of trauma, the trauma's community, and the audiences. ${ }^{46}$ This is what Friedländer calls the "unease in historical interpretation," which is the "noncongruence of intellectual interpretation and blocking of intuitive comprehension." ${ }^{47}$ This "unease" is also present in this volume: while I strive to establish the facts of what happened and I also try to describe the perspective of the actors, including survivors and perpetrators. This would be unimaginable had I insisted on using a positivist approach, i.e. if I had tried to figure what "objectively" happened. I certainly aimed at maximum objectivity, but I was also aware of my profession's boundaries.

The tenants of Csengery 64 were assimilated Jews, during the interviews no one claimed to have practiced their religion nor to have been exposed to anti-Semitic atrocities before the German occupation. Similarly, there was no mention of previous political involvement either. For them the politics of the Horthy regime was a farce concocted by the elites, which did not affect them until the Anti-Jewish Laws were introduced in 1938. I am of course aware that they must have had preliminary experiences of everyday anti-Semitism, but those were not central in the interviews because the life-threatening events of the German occupation overshadowed whatever happened earlier.

The case carries further moral lessons about the way the invisible tension between ethnicities exploded, and the way the Jewish tenants came to know the real Christian janitors. Ethnic cleansing is often accompanied by crimes against property, because the collapse of the state is an opportunity for murder, plunder and pillage with no consequences. ${ }^{48}$ The violence against Jews in particular can be explained with a desire for revenge for earlier political decisions that were connected with Jewish interests, as well as by anti-Semitic hatred and eco-

46 From Ross Chambers, "Orphanated Memories, Phantom Pain. Towards Hauntology of Discourse," Untimely Interventions. Quoted in Thomas Treize, "Between History and Psychoanalyses. A Case Study in the Reception of Holocaust Survivor Testimony," History and Memory 1 (2008): 36.

47 Saul Friedländer, Memory, History, and the Extermination of the Jews of Europe (Bloomington: Indiana University Press, 1993), 111.

48 Norman Naimark, Fires of Hatred. Ethnic Cleansing in Twentieth-Century Europe (Cambridge, Mass.: Harvard University Press, 2001), 8. 
nomic rivalry. ${ }^{49}$ The Csengery Street event was most probably primarily a robbery with which the perpetrators tried to enhance their financial situation in the historical moment of the Arrow Cross coup. Piroska Dely lived on Dob Street 74, around the corner from Csengery Street, and was therefore close to the crime scene. She was also well acquainted with the wealth of the Jewish families in the neighborhood. Before October 15, 1944, she had already participated in the robbing of Jews forced to live in yellow star houses, i.e. independent of the Arrow Cross seizure of power. She was put on trial after the liberation of Budapest for one of these minor robberies, and it was during this trial that Andor Lichter, who lived in Csengery utca - who had lost his mother, father, and son during the massacre - identified her.

The survivors of the Csengery Street massacre erected the first privately funded Holocaust memorial in Budapest. The memory plaque (see appendix 6) exhibits the 19 names of people murdered in their homes on October 15, 1944. ${ }^{50}$ The memory plaque was inaugurated on October 15, 1945, and is a homage to the resourcefulness and organization skills of survivors as it is there to this day (see appendix 8). The story of the plaque is paradigmatic of post-1945 memory culture: it shows how the spaces of remembrance were shaped and reshaped by subsequent regimes of memory. During my personal meetings with the survivors they shared their memories about the massacre, the erection of the plaque and its upkeep especially after 1989 when it became increasingly endangered.

The massacre in Csengery 64 qualifies as important due to the place, space, and timing of the events. The available archival sources press material together with interview material offer a unique insight into life and feelings of survivors and perpetrators together with its unique memorialization practice are important for understanding a new and rarely analyzed aspect of the Holocaust: a mass killing in Budapest committed very possibly by Hungarians allegedly led by a woman. The history of the post-1945 period is characterized by forgetting, as silencing and omission were parts of a strategy of survival. This case, which had been a high-profile court case right after the liberation, proves that the strategy of forgetting had no alternative when a narratable story needs to be constructed from different stories. On the other hand, even telling the story of this massacre during this high-profile court case contributed to a selective forgetting of some aspects of this event.

49 Jeffrey S. Kopstein and Jason Wittenberg, Intimate Violence. Anti-Jewish Pogroms on the Eve of the Holocaust (Ithaca, NY: Cornell University Press, 2018).

50 The issues concerning the number of victims will be discussed in a separate chapter. There are 19 names on the commemorative plaque. 